\title{
GIP Regimen
}

National Cancer Institute

\section{Source}

National Cancer Institute. GIP Regimen. NCI Thesaurus. Code C161946.

A chemotherapy regimen consisting of gemcitabine, ifosfamide, and cisplatin that may be useful in the treatment of certain germ cell tumors. 